\title{
Prevention by Mannan and other Sugars of in Vitro Damage of Rat Fetal Small Intestine Induced by Cereal Prolamin Peptides Toxic for Human Celiac Intestine ${ }^{1}$
}

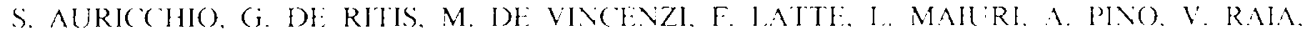 \\ A.VI) V. SII.A.V(

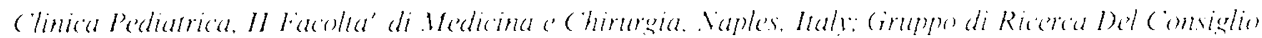

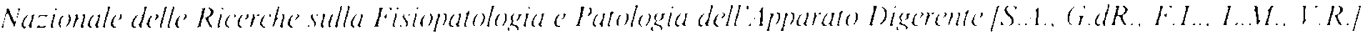

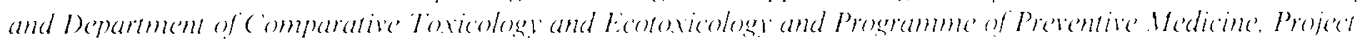

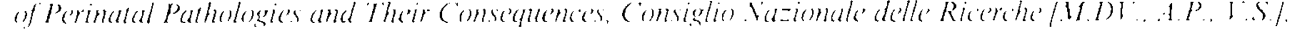
Romé, lials

\begin{abstract}
ABSTRACI. Peptic-tryptic-cotazym and peptic-tryptic digests were obtained, simulating in vivo protein digestion, from pure "bread" wheat gliadins and from rye, barley, and oats prolamine and tested on small intestine cultures from fetal rats. When tested at a concentration of $0.1 \mathrm{mg}$ of peptides $/ \mathrm{ml}$ of culture medium the peptic-tryptic-cotazym and peptic-tryptic digests of gliadin and prolamines were very active in slowing in vitro development of fetal rat intestine and in increasing the occurrence and severity of degenerative changes. The ability of some sugars to interfere with inhibition of fetal intestinal morphogenesis induced by these peptides was also tested. Mannan at a concentration of $0.1 \mathrm{mM}$ was effective in allowing intestinal morphogenesis to take place in the presence of prolamine peptic-tryptic-cotazym and prolamine peptic-tryptic digests of the four toxic cereals. Some oligomers of N-acetylglucosamine were also effective in blocking the inhibitory effect of "bread" wheat gliadin peptides. These data are compatible with the hypothesis that some sugars may exert a protective effect on the toxic activity of cereal prolamin peptides on the human celiac intestine. (Pediatr Res 22: 703-707, 1987)
\end{abstract}

\section{4 breviations}

P'TC, peptic-tryptic-eotarym

P'T, peptic-tryptic

Ceilic discase is a well-known enteropathy whose symptoms are iriggered by the presence in the diet of wheat. barley. rye. or oats. Rice and maize are well tolerated by celiac patients. Falchuk $\because$ (a. (1) have proposed the organ culture of human small it cestinal biopsies as an in ritro model of celiac disease. Flat intestinal mucosa of celiac patients with active discase showed morphological and biochemical improvement when cultured in a gluten-free medium. However, no improvement occurred when the tissue was cultured in the presence of gliadin fractions or peptides $(2-5)$. In this system. mannan exhibited a protective

Recoived Januatry 6, 1987: accopted Augus 4, 1987

Correspondence Prol. Salvatore Auricchio. (linical Pediatrica. Il Facolta of Medicina ( hirumgia Via S.Pansini 5.80131 Vaples. llaily

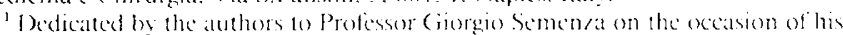
60 th birthdily. effect and allowed morphological improvement of intestinal mucosa specimens of patients with active celiac discase also in the presence of wheat gliadin peptides (6).

Prolamin peptides from all the toxic cereals in celiac discase as well as some peptides prepared from $\mathrm{A}$-gliadin (7). which are toxic in vitro for human atrophic small intestinal mucosa (8). are all able to agglutinate undifferentiated $K 562$ (S) cells (9). 10). However, prolamin peptides from rice and maize (10) and the peptides of $\mathrm{A}$-gliadin which are not able to damage the cultured celiac mucosa (7). do not agglutinate these cells. Mannan and oligomers of $\mathrm{N}$-acetyl-glucosamine. $N$, N'-diacetylchitobiose and $N$. $N^{\prime}$. N"-triacetylehitoriose were vers effective in inhibiting the agglutinating activity of prolamin peptides obtained from bread wheat. barlew. ree and oats as well as that of the active $\mathrm{A}$-gliadin peptides.

Gliadin peptides are also able to reversibly inhibit the development and morphogenesis of the immature small intestine from 17-day-old rat fetus. whereas they have no effect on the in vitro cultured. differentiated jejunum from 21-day-old rat fetus (11. 12). Moreover prolamin peptides from rve. oats. barley and sorghum show in this in vitro system an activity similar to bread wheat gliadin peptides. whereas prolamin peptides from rice and maise are inactive (13)

Herein we describe the results of further investigations undertaken to confirm the hypothesis that the in vitro loxic effects induced by bread wheat, barley, rye, and oats on ret fetus intestinal mucosa mav be prevented by mannan and other sugars.

\section{MATHRIAIS AND METHODS}

Pure bread wheat (Triticum aestivm var. S. Pastore), rise (Oriza sativa var. Roma). maize (Yed mals var. B 73). rye (Secale cerecale var. 500 2(i), barley (Hordentm vulgeme var. Arma). sorghum (Sorghum vulgare var. NK 120). and oats ( Hence satise var. Astra) were kindly supplied by the Istituto Sperimentale per la Cerealicoltura. Rome. Italy. Prolamin fractions were extracted from the above mentioned cereals with an experimental procedure identical to that described by suricehio et al. (13). Pre digests of the prolamin fractions were prepared as described by Auricehio (" al. (1.3). P'T digests of the purified prolamin fractions were prepared following a two-step procedure reported by de Ritis at al. (12): in order to inactivate the proteolytic enzymes. PI digests were submitted to heating at $100^{\circ}($ for $30 \mathrm{~min}$

Mannan. a mannose homopolysaccharide. Was obtained from Sacharomedes cerevisiae (Sigma (hemical company. Si. Iouis. 
$\mathrm{MO}$ ). $\mathrm{N}, \mathrm{N}^{\prime}$-diacetylchitobiose and $\mathrm{N}, \mathrm{N}^{\prime}, \mathrm{N}^{\prime \prime}$-triacetylchitotriose were prepared from Sigma Chemical Company.

For the in vitro culture of fetal jejunum, pregnant Wistar rats were anesthetized with ether and 17-day-old fetuses were removed at laparotomy. Fetal jejunum segments were isolated and cultured in vitro for $48 \mathrm{~h}$ in a serum-free medium according to the method described by de Ritis et al. (14). Jejunal segments from the same fetus were cultured in the absence and in the presence of the above mentioned digests. All the peptide mixtures were sterilized before addition to the incubation medium by filtration through $0.22 \mathrm{~m} \mu$ Millipore filters. Differentiation of fetal rat jejunum was followed morphologically by light microscopy as reported by de Ritis et al. (14) without knowledge of the culture conditions. A morphologic assessment of histologic changes during organ culture of 17-day-old fetus intestine was performed on the more external part of the tissue where the epithelium showed more clearly developmental changes in the absence of gliadin peptides. In this part of the tissue specimen we constantly observed well-formed villi that do not develop in the more internal part of the intestinal segment probably as the consequence of the more difficult penetration of the tissue by the culture medium. The first five sections were cut off and the following 10-20 sections were evaluated. No appreciable variations in the developmental pattern of intestinal mucosa were observed among these histologic sections.

\section{RESULTS}

Before culture, jejunal mucosa from forty five 17-day-old fetuses did not show any villus, and only undifferentiated cuboidal stratified epithelia lining the lumen were present (Figs. $1 \mathrm{~A}$ and 2A); no goblet cells could be detected in any uncultured fetuses (Tables 1 and 2). After $48 \mathrm{~h}$ of in vitro culture in the absence of peptides (Tables 1 and 2), formed villi were present in 33 fetal jejunum segments (Figs. $1 B$ and $2 B$ ) and rudimentary villi were observed in jejunal segments from 10 other fetuses: villi did not develop in only two cultured fetuses. In all 45 cultured fetuses the epithelial lining consisted exclusively of simple columnar epithelium and goblet cells were present in 21 fetuses. Slight patchy degenerative changes were observed only in a few cultured jejunal segments from one fetus. These findings confirm previous results by de Ritis et al. (12) and Auricchio et al. $(11,13)$ showing that differentiation and maturation of small intestinal mucosa from rat fetuses take place in vitro in a way comparable to in vivo conditions.

When tested at a concentration of $0.1 \mathrm{mg}$ of peptides $/ \mathrm{ml}$ of culture medium the prolamine-PTC and prolamine-PT digest from bread wheat, rye, oats, and barley were very active in slowing down in vitro development of fetal rat intestine and in increasing occurrence and severity of degenerative changes ( $\mathrm{Ta}-$ bles 1 and 2). After $48 \mathrm{~h}$ culture in the presence of PTC or PT of prolamines digests from the four toxic cereals, well-developed villi were absent in most cultures (Figs. $1 C$ and $2 C$ ) and rudimentary villi were present only in a few cultures. Furthermore goblet cells were present only in one culture with prolamin peptides from oats (Tables 1 and 2). Av silable findings do not indicate any significant difference between activities of PT- or PTC-digests of prolamines from each cereal in slowing down in vitro development of fetal rat intestine.

We also tested the ability of some sugars to interfere with inhibition of fetal intestinal morphogenesis induced by peptides of bread wheat, barley, rye, and oat prolamines. The data summarized in Tables 1 and 2 show that mannan at a concentration of $0.1 \mathrm{mM}$ was largely effective in allowing intestinal morphogenesis to take place in the presence of PTC- or PT-digests of prolamines from any of the four toxic cereals (Fig $1 D$ ). Mannan did not show any effect on the in vitro development of the fetal rat intestine in the absence of toxic prolamine peptides. N, $\mathrm{N}^{\prime}$ diacetylchitobiose and $N, N^{\prime}, N^{\prime \prime}$-triacetylchitotriose at a concentration as low as $3 \mathrm{mM}$ were both effective (Fig. 2D) and completely removed the inhibitory effect of bread wheat gliadin peptides. Mannose and $\mathrm{N}$-acetylglucosamine were ineffective even when tested at concentration as high as 50 and $200 \mathrm{mM}$. respectively.
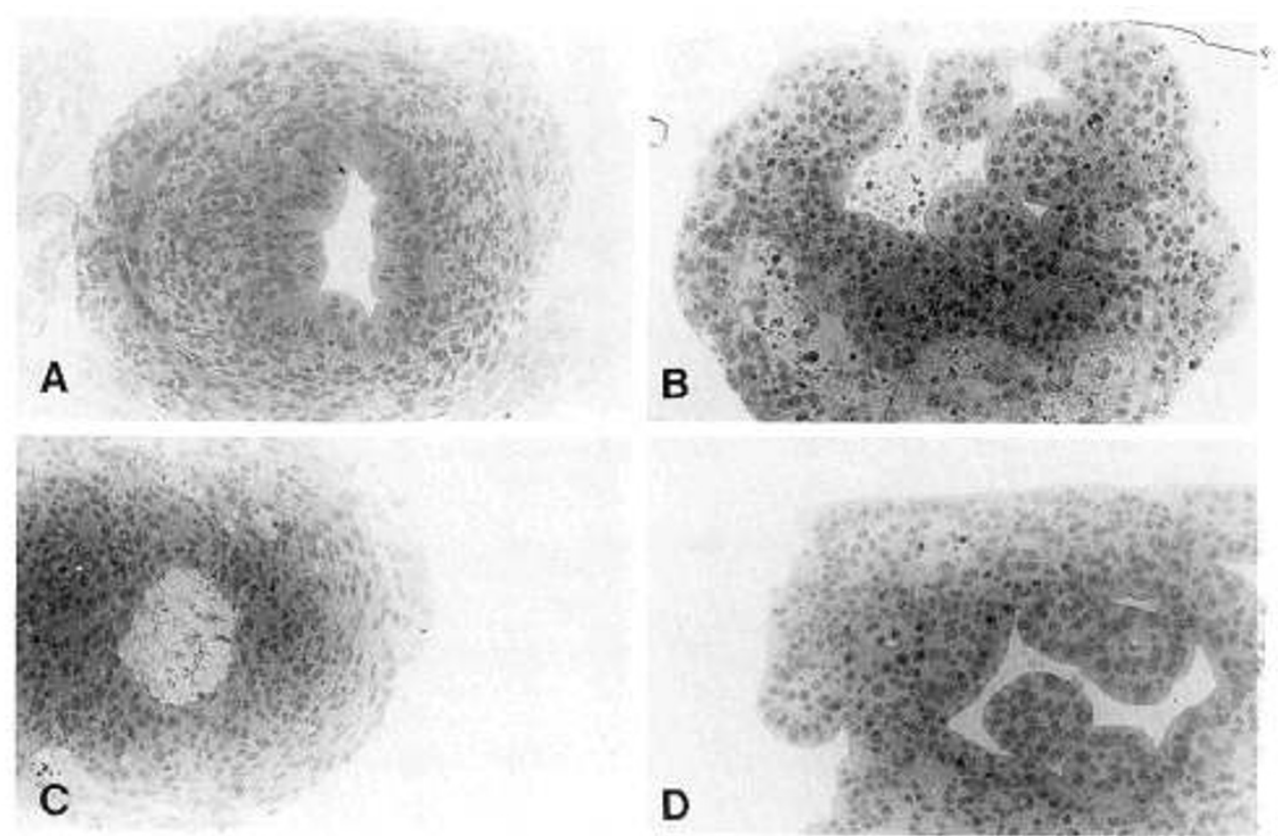

Fig. 1. Effect of PT digest of prolamines from barley and protective effect of mannan on in vitro development and morphogenesis of jejunum from 17-day-old rat fetus. $A$, jejunal mucosa before culture. The epithelium consists of stratified undifferentiated cells and no villi are present. $B$, jejunal mucosa after $48 \mathrm{~h}$ culture and $D$. jejunal mucosa after 48 - $\mathrm{h}$ culture in the presence of the PT prolamin digest $(0.1 \mathrm{mg} / \mathrm{ml})$ from barley and mannan $(0.1 \mathrm{mM})$ : well-developed villi and an epithelium consisting of single laver of relatively differentiated cells are evident. $C$, jejunal mucosa after $48-\mathrm{h}$ culture in the presence of the prolamin digest $(0.1 \mathrm{mg} / \mathrm{ml})$ from barley. No villi developed on the surface which is lined by cuboidal and columnar epithelial cells. Degenerative changes are evident. 

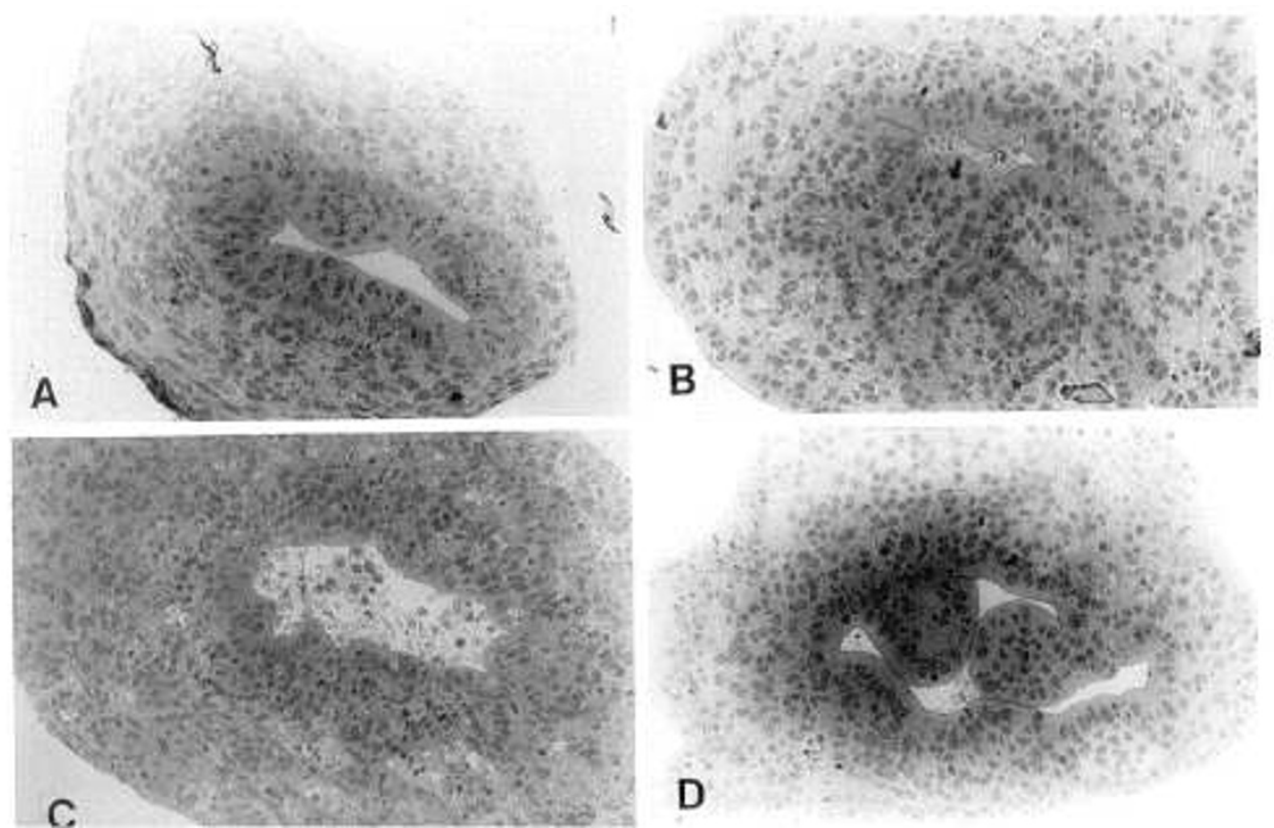

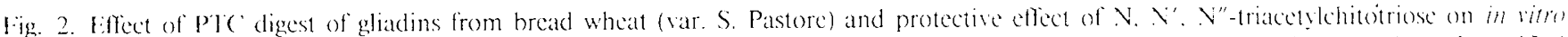
development and morphogenesis of jejunum from 17-day-old rat fetus. A. jejunal mucosa before culture. The epithelium consists of stratitied undifferentiated cells and no villi are present. 3 . jejunal mucosia after 48 -h culture and $I$ ). jejunal mucosa after 48 -h culture in the presence of $P ' T$. gliadin digest $\left(0.1 \mathrm{mg} / \mathrm{ml}\right.$ ) of bread wheat (var. S. Pastore) and $\therefore . \mathrm{N}^{\prime} . \mathrm{N}^{\prime \prime}$-triacetykhitotriose $(3 \mathrm{mM})$ : well-develeped villi are present which are lined by a single layer of differentiated columnar epithelial cells. ( jejunal mucosa after 48 -h culture in the presence of PT gltadin digest (0) 1 mg/ $\mathrm{ml}$ ) of bread wheat (var. S. Pastore). Villi are absent from the mucosal surface which is lined primarily by columnar epithelial cells. Degencrative changes are evident.

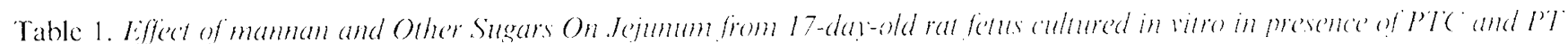
gliadin peptickes from hexaploid wheat

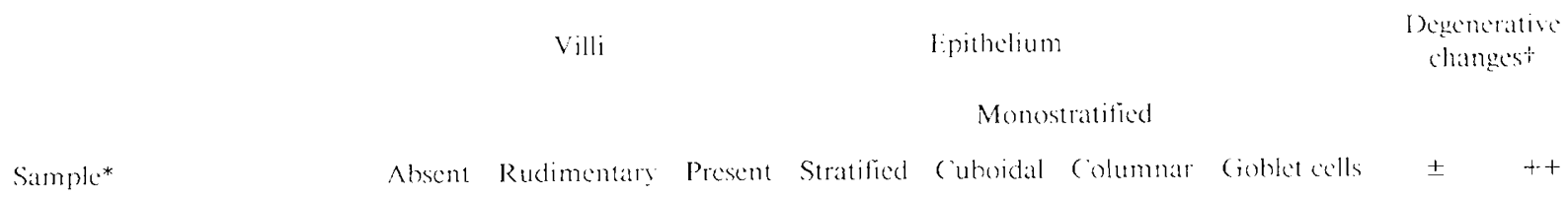

Uncultured 17-diay-old fetuses (32) 32 32

After 48-1 culture

Without peptides ${ }^{\prime \prime}$

Giliadin peptides from hexaploid wheat $(0.1 \mathrm{mg} / \mathrm{mlts}$

(iliadin peptides from hexaphoid

wheat () $.1 \mathrm{mg} / \mathrm{ml}+\operatorname{mannan}(0.1$ $m M\|\| \|^{\prime}$

Gliadin peptides from hexaploid wheat $0.1 \mathrm{mg} / \mathrm{ml}+$ diacetychitobiose $3 \mathrm{mM}^{* *}$

(iliadin peptides from hexaphoid wheat $0.1 \mathrm{mg} / \mathrm{ml}+$ triacets $/ \mathrm{chl}$ -

$\begin{array}{llll}(32) & 2 & 8 & 22\end{array}$

(36) 31

(37) 3

5

15

19 totriose $3 \mathrm{mM}+1$

* Number of fetuses examined or of fetal jejuna cultured is shown in parentheses.

+ \pm , slight degenerative changes: ++ . large necrotic areas.

IS Six cultures at $0.5 \mathrm{mg} / \mathrm{ml}$.

SIifteen cultures with P'l gliadin peptides.

|| Iight cultures at $0.5 \mathrm{mg} / \mathrm{ml}$.

If Twenty cultures with P'I gliadin peptides.

** ()ne culture at $1 \mathrm{mg} / \mathrm{ml}$.

Ho One culture at $2 \mathrm{mg} / \mathrm{ml}$.

Frequency distribution analysis by $x$. The two groups rudimentary and present are pooked for the analysis.

"Difference from the value before culture. $x$ " $=49.05 . p<0.0(1)$.

"Difference between the values after culture with and without peptides. $x^{*}=40.11 . p<0.0(0)$.

Difference between the values after culture with gliadin peptides and gliadin peptides with mannan. $x^{2}=41.35 .1,<0 .(0) 1$. 
Table 2. Effect of mannan on jejunum from 17-day-old fetus cultured in vitro in presence of PT prolamin peptides from different cereals

\begin{tabular}{|c|c|c|c|c|c|c|c|c|c|c|}
\hline \multirow[b]{3}{*}{ Sample* } & & \multirow[b]{3}{*}{ Absent } & \multicolumn{2}{|l|}{ Villi } & \multicolumn{3}{|c|}{ Epithelium } & \multirow[b]{3}{*}{ Goblet cells } & \multicolumn{2}{|c|}{$\begin{array}{c}\text { Degenerative } \\
\text { changes } \dagger\end{array}$} \\
\hline & & & \multirow[b]{2}{*}{ Rudimentary } & \multirow[b]{2}{*}{ Present } & \multirow[b]{2}{*}{ Stratified } & \multicolumn{2}{|c|}{ Monostratified } & & \multirow[b]{2}{*}{ \pm} & \multirow[b]{2}{*}{++} \\
\hline & & & & & & Cuboidal & Columnar & & & \\
\hline Uncultured 17-day-old fetuses & (I3) & 13 & & & 13 & & & & & \\
\hline \multicolumn{11}{|l|}{ After 48 -h culture } \\
\hline Without peptides ${ }^{a}$ & $(13)$ & & 2 & 11 & & & 13 & 6 & 1 & \\
\hline $\begin{array}{l}\text { Prolamin peptides from barley } \\
0.1 \mathrm{mg} / \mathrm{ml}^{b}\end{array}$ & $(11)$ & 8 & 3 & & & 2 & 9 & 1 & 7 & \\
\hline $\begin{array}{l}\text { Prolamin peptides from barley } \\
0.1 \mathrm{mg} / \mathrm{ml}+\text { mannan } 0.1 \\
\mathrm{mM}^{c}\end{array}$ & $(15)$ & 2 & 2 & 11 & & & 15 & 7 & 5 & 2 \\
\hline $\begin{array}{l}\text { Prolamin peptides from rye } 0.1 \\
\mathrm{mg} / \mathrm{ml}^{b}\end{array}$ & $(12)$ & 9 & 3 & & & 4 & 8 & & 5 & 5 \\
\hline $\begin{array}{l}\text { Prolamin peptides from rye } 0.1 \\
\mathrm{mg} / \mathrm{ml}+\text { mannan } 0.1 \mathrm{mM}^{c}\end{array}$ & (13) & & 8 & 5 & & & 13 & 4 & 8 & 1 \\
\hline $\begin{array}{l}\text { Prolamin peptides from oat } 0.1 \\
\mathrm{mg} / \mathrm{ml}^{b}\end{array}$ & (13) & 9 & 3 & 1 & & 1 & 12 & 1 & 7 & 2 \\
\hline $\begin{array}{l}\text { Prolamin peptides from oat } 0.1 \\
\mathrm{mg} / \mathrm{ml}+\text { mannan } 0.1 \mathrm{mM}^{c}\end{array}$ & (12) & 2 & 6 & 4 & & & 12 & 4 & 5 & 2 \\
\hline
\end{tabular}

* Number of fetuses examined or of fetal jejuna cultured is shown in parentheses.

$\dagger \pm$, slight degenerative changes; ++ , large necrotic areas.

$\ddagger$ One culture at $0.5 \mathrm{mg} / \mathrm{ml}$.

Frequency distribution analysis by $\chi^{2}$. The two groups rudimentary and present are pooled for the analysis.

${ }^{a}$ Difference from the value before culture, $\chi^{2}=15.38, p<0.001$.

${ }^{b}$ Difference between the values after culture without peptides and with prolamin peptides $p<0.01$ : barley $\left(\chi^{2}=8.15\right)$; rye $\left(\chi^{2}=9.14\right)$; oat $\left(\chi^{2}=\right.$ 7.9).

${ }^{c}$ Difference between the values after culture with prolamin peptides and prolamin peptides with mannan: barley $\left(\chi^{2}=8.1, p<0.01\right)$; rye $\left(\chi^{2}=\right.$ $9.14, p<0.01)$; oat $\left(\chi^{2}=5.02, p=0.02\right)$.

\section{DISCUSSION}

The mechanism of the toxic action of some cereal proteins on celiac intestine is still unknown. An abnormal immune response to these proteins has been postulated as the basis for the mucosal damage in celiac patients $(15,16)$. However, evidence for a direct toxic action of gliadin peptides on the small intestinal mucosa in some phases of its development and morphogenesis comes from our previous studies (11-13) and from the data presented herein, showing that the rat fetal intestine culture is an adequate model of screening and investigating cereal peptides which are toxic for celiac small intestinal mucosa. In particular, we have shown that this in vitro system responds not only to PTC digests of toxic prolamins fractions (13), but also to PT digests.

We have also demonstrated herein that mannan is able to protect fetal intestinal mucosa from in vitro effects of all the toxic prolamin peptides. These findings are likely related to the fact that mannan is also able to prevent $\mathrm{K} 562$ (S) cell agglutination induced by gliadin and prolamin peptides from toxic cereals in celiac disease $(9,10)$ and is able to protect in vitro cultured atrophic celiac mucosa from the damaging effect of gliadin peptides (6).

Similar considerations apply to the results obtained with $\mathrm{N}$ acetylglucosamine oligomers, i.e. $\mathrm{N}, \mathrm{N}^{\prime}$-diacetylchitobiose and $\mathrm{N}, \mathrm{N}^{\prime}, \mathrm{N}^{\prime \prime}$-triacetylchitotriose. The results indicate the highly significant correlation existing, for all the sugars tested, between inhibition of agglutinating activity on K 562 (S) cells and protection of rat fetal intestine from in vitro damaging effect of toxic gliadin peptides.

Such protective effects would be compatible with the hypothesis that the peptides were acting as lectins in these in vitro systems. However, conflicting results have been reported on the lectin activity of gliadin peptides (17-20). Whatever the mechanism of sugars might be, the problem arises whether these in vitro studies apply to the in vivo situation; i.e. whether a similar protective effect might be observed in vivo on the celiac small intestine exposed to the toxic cereals after opportune administration of adequate amounts of sugars.

Acknowledgments. The authors thank Francesco Paparo for the technical assistance.

\section{REFERENCES}

1. Falchuk ZM, Gebhard RL, Sessoms C, Strober W 1974 An in vitro model of gluten sensitive enteropathy: effect of gliadin on intestinal epithelial cells of patients with gluten-sensitive enteropathy in organ culture. J Clin Invest 53:487-500

2. Fluge G, Aksnes L 1981 Morphological and morphometric assessment of human duodenal biopsies maintained in organ culture. Scand J Gastroenterol 16:555-567

3. Howdle PD, Ciclitira PJ, Simpson FG, Losowsky MS 1984 Are all gliadins toxic in celiac disease? An in vitro study of alpha, beta, gamma and omega gliadins. Scand J Gastroenterol 19:41-47

4. Howdle PD, Corazza GR, Bullen AW, Losowsky MS 1981 Gluten sensitivity of small intestinal mucosa in vitro: quantitative assessment of histological change. Gastroenterology 80:442-450

5. Jos J, Lenoir G, de Ritis G, Rey J 1975 In vitro pathogenetic studies of celiac disease. Effect of protein on celiac intestinal biopsy specimens maintained in culture for $48 \mathrm{hrs}$. Scand J Gastroenterol 10:121-128

6. de Ritis G, Auricchio S, De Vincenzi M, Mancini E, Minetti M, Sapora O, Silano V 1984 Mannan prevents the in vitro toxicity of gliadin peptides (gp) on cultures of celiac mucosa and fetal rat intestine. Pediatr Res 18:1052(abstr)

7. Auricchio S, D'Auria G, de Ritis G, De Vincenzi M, Maiuri L, Mancini E Pavone V, Silano V Cell agglutinating activity of highly purified peptide fragments from bread wheat A-gliadin and A-gliadin related synthetic peptides. Pediatr Res (in press)

8. de Ritis G, Auricchio S, Jones HW, Lew EJ-L, Bernardin JE, Kasarda DD In vitro (organ culture) studies of the toxicity of specific A-gliadin peptides in celiac disease. Gastroenterology (in press)

9. Auricchio S, de Ritis G, De Vincenzi M, Mancini E, Minetti M, Sapora O, Silano V 1984 Agglutinating activity of gliadin peptides from bread wheat: implication for celiac disease pathogenesis. Biochem Biophys Res Commun 121:428-433

10. Auricchio S, de Ritis G, De Vincenzi M, Silano V 1985 Toxicity mechanisms of wheat and other cereals in celiac disease and related enteropathies. J Pediatr Gastroenterol Nutr 4:923-930

11. Auricchio S, de Ritis, G, De Vincenzi M, Occorsio P, Silano V 1982 Effect of 
gliadin peptides prepared from hexaploid and tetraploid wheat on cultures of intestine from rat fetuses and celiac children. Pediatr Res 16:10(04-1010)

12. de Ritis (; Occorsio P. Auricchio S. (iramenzi F. Morisi G. Silano V 1979 Toxicity of wheat flour proteins and protein-derived peptides for in vitm developing intestine from rat fetus. Pediatr Res 13:1255-1261

13. Auricehio S. (ardelli M. de Ritis (i. I) Vineenzi M. I atte I. Silano V 1984 An in virro animal model for the study of ereal components toxic in celiac An in vilfo andmal model for the stat
discase. Pediatr Res 18:1372-1378

14. de Ritis (;. Falchuk 7.M. Trier JS 1982 Differentiation and maturation of cultured fetal rat jejunum. I)ev Biol 45:3014-317

15. Strober $\mathrm{W} 1978 \wedge \mathrm{n}$ immunofogical theory of gluten-sensitive enteropaths. In: Mc Vicholl B. MC Carthy ( I: Fottrell IF" (eds) Perspectives in (eliac Discase. University P'ark Press, Baltimore. no 169-182
16. Kagnoff MI: Austin RK. Hubert IJ. Bernardin Jl: Kasarda I)1 1984 Possible role for a human adenovirus in the pathogenesis of celiac disease fl lap Med $160.15 .44-1557$

17. Kottgen E. Volk B. Kluge $F$. Gerok $W 1982$ A kectin with ofigomannosy specificity and the causative agent of gluten sensitive enteropathy. Biechem Biophys Res (ommun 109:168-173

18. (olver J. Farthing MJ (;. Kumar PJ (Cark Mll Ohannesian AI). Waldron VM 1986 Reappraisal of the "lectin hypothesis" in the aetopathogenesis of celiac discase. (lin Sci 71:105-110

19. Rawcliffe PM. Priddle JI). Jewell DP 1985 (Cotiac discase: possible mannosespecific lectin activity of gluten. (lin Sci $(6): 111$ )

20. Kolberg J Sollid I. 1985 Iectin activity of gluten identified as wheat germ agglutinin. Biochem Biophys Res Commun 130:867-872 